\title{
VIABILITAS DAN STRUKTUR MIKROKAPSUL Lactobacillus acidophilus DENGAN BAHAN PENYALUT KARAGINAN SEMI MURNI JENIS Eucheuma cottonii
}

\author{
Oleh:
}

\section{Dwi Setijawati $^{1}$, Susinggih Wijana ${ }^{1}$, Aulaniam1,Imam Santosa ${ }^{1}$}

Tenaga Pengajar Fakultas Perikanan dan Ilmu Kelautan (mahasiswa pasca Sarjana), tenaga pengajar Fakultas Teknologi Pertanian (sebagai promotor), Tenaga pengajar Fakultas MIPA (sebagai Co-promotor), tenaga pengajar Fakultas Teknologi Pertanian (sebagai Co-promotor) Universitas Brawijaya Malang

\begin{abstract}
Abstrak
Eucheuma cottonii adalah rumput laut merah, penghasil kappacaragenan, yang terdiri dari $\beta$-D-galactopyranosyl-4-sulphate dan $\alpha$-D3,6 anhydrogalactopyranosyl residu (Stanley, 1990). Eucheuma cottonii dalam bentuk SRC (semi Refine Caragenan) atau karaginan semi murni dapat dimanfaatkan sebagai bahan penyalut pada proses mikroenkapsulasi.Pemanfaatan ini ditinjau dari sifatnya sebagai penggel, dengan karakteristik gel yang keras dan kokoh tetapi gampang pecah. Tujuan penelitian adalah mempelajari Eucheuma cottonii dalam bentuk karaginan semi murni sebagai bahan penyalut Lactobacillus acidophilus berdasarkan viabilitasnya dan struktur mikrokapsul setelah melewati $\mathrm{pH} 2$ dan $\mathrm{pH} 7$ secara in vitro. Materi penelitian menggunakan :1) karaginan semi murni atau SRC dari jenis Eucheuma cottonii,2) mikrokapsul Lactobacillus acidophilus dengan metoda Adhikari (2003), Metoda penelitian menggunakan laboratorium experimental dan desain uji ANOVA untuk mencari pengaruh, dilanjutkan dengan uji BNT ,viabilitas Lactobacillus acidophilus menggunakan MRS Agar dengan metoda tuang, struktur mikrokapsul secara deskriptif diamati dengan alat Confocal Laser Scanning Microscope. Hasil penelitian menunjukkan viabilitas Lactobacillus acidophilus dipengaruhi oleh kondisi $\mathrm{pH}$ dan menurun viabilitasnya setelah perlakuan $\mathrm{pH} 2$ dengan rata-rata viabilitas sebesar $10^{2} \mathrm{cfu} / \mathrm{ml}$ dan rata-rata viabilitas sebesar $10^{3} \mathrm{cfu} / \mathrm{ml}$ pada $\mathrm{pH}$ 7. Mikrokapsul mempunyai ukuran 60 um setelah diperlakukan pada $\mathrm{pH} 2$ dan 50 um setelah diperlakukan pada $\mathrm{pH} 7$.
\end{abstract}

Keywords : SRC Eucheuma cottonii, mikroenkapsulasi, Lactobacillus acidophilus 


\begin{abstract}
Eucheuma cottonii is red hydrocolloids, producing kappa-caragenan, consisting of $\beta$-D-galactopyranosyl-4-sulphate dan $\alpha$-D-3,6 anhydrogalactopyranosyl residu (Stanley, 1990) . Eucheuma cottonii in Semi Refine Caragenan (SRC) formed,it could be used as encapsulated material on microencapsulation process, looking for it gel properties. Kappa-caragenan has strong and rigid gel but brakable characteristic.Aimed of this research was to study Eucheuma cottonii in SRC formed as encapsulated material toward it's viability and microcapsule structure after passage $\mathrm{pH} 2$ and $\mathrm{pH} 7$ in vitro treatment. Material research was SRC Eucheuma cottonii (PNG process), Lactobacillus acidophilus microcapsule by Adhikari (2003). Research Method was experimental laboratorium, using ANOVA design analysed by SPSS software. Descriptive of microcapsule structure using CLSM (Confocal Laser Scanning Microscope), Viability of Lactobacillus acidophilus using MRS Agar (Pour Plate Agar Methods). The result was Lactobacillus acidophilus viability affected by $\mathrm{pH}$, and decreased from $10^{5} \mathrm{cfu} / \mathrm{ml}$ (kontrol) to $10^{2} \mathrm{cfu} / \mathrm{ml}$ and $10^{3} \mathrm{cfu} / \mathrm{ml}$ after passage through pH 2 and pH 7 treatment. Diameter size of microcapsules was $60 \mathrm{um}$ after $\mathrm{pH} 2$ treatment and $50 \mathrm{um}$ after $\mathrm{pH} 7$ treatment .
\end{abstract}

Keywords:SRC Eucheuma cottonii, Lactobacillus acidophilus microencapsulation

\section{PENDAHULUAN}

Indonesia hidrokoloid jenis Eucheuma sp terbesar no 2 setelah Filipina. Eucheuma sp mempunyai 2 jenis, yaitu Eucheuma cottonii dan Eucheuma spinosum. Eucheuma cottonii dapat diekstrak untuk menghasilkan karaginan, dengan perlakuan alkali dan metoda proses yang berbeda. Eucheuma cottonii akan menghasilkan tipe kappacaragenan, dengan sifat gel yang keras dan kokoh. Salah satu metoda proses yang umum digunakan untuk mengekstrak adalah metoda pemanasan dengan alkali.

Pemanfaatan Eucheuma sp dengan hasil ekstrak karaginan adalah sebagai bahan pengenkapsulat (encapsulating 
agent) pada metoda mikroenkapsulasi.

Mikroenkapsulasi adalah teknik enkapsulasi bahan inti yang berbentuk padatan, cairan, maupun gas dengan suatu bahan penyalut. Miroenkapsulasi bertujuan untuk melindungi bahan inti dari kehilangan nilai gizi, menstabilkan bahan aktif, memudahkan pengendalian pelepasan bahan aktif dan melindungi komponen aktif dari lingkungan. Perkembangan penggunaan produk mikroenkapsulasi dengan metodanya yang berbeda dan bahan pengenkapsulatnya saat ini menjadi perhatian utama (Kondo, 1979).

Pada

metoda mikroenkapsulasi akan melibatkan interaksi antara bahan pengenkapsulat (cell material), inti (Core material) , teknik mikroenkapsulasi yang sesuai yang akan bekerja secara sinergis. Inti adalah bahan yang akan disalut, sedangkan penyalut adalah bahan yang digunakan untuk menyalut inti (pengenkapsulat). Keberhasilan proses mikroenkapsulasi sangat bergantung kepada pemilihan bahan penyalut dalam prosesnya (Kondo, 1979; Mosilhey, 2003).
Penggunaan mikroenkapsulasi saat ini yang penting adalah pada produk probiotik dan prebiotik Prebiotik adalah bahan penyalut, yang biasanya dari kelompok hidrokoloid. Bahan yang biasa digunakan sebagai bahan penyalut adalah polimer organik atau non organik baik berasal dari bahan alam atau buatan. Bahan penyalut yang dipilih dalam proses enkapsulasi haruslah dapat memberikan suatu lapisan tipis yang kohesif dengan inti, tercampur secara kimia dan tidak bereaksi dengan inti, serta mempunyai sifat yang sesuai dengan tujuan penyalutan (kuat, fleksibel, impermeabel, stabil dan bersifat optis) (Lachman et al, 1994). Caragenan adalah bahan yang tergolong dalam kelompok GRASS (Generally Recognized As Save). Beberapa macam bahan pengenkapsulat terutama xanthan gum dan caragenan sama seperti alginat adalah bahan pengenkapsulat yang dapat melindungi bakteri probiotik secara efektif dari tekanan kondisi lingkungan (Ding W.K, and Shah N.P, 2009).Chibata melaporkan bahwa k-caragenan dapat digunakan sebagai media imobilisasi sel. Sedangkan Audet et al(1989) menyebutkan bahwa 
enkapsulasi probiotik jenis Lactobacillus delbruecki spp, bulgaricus dan Str. Thermophilus menggunakan 3\% kappacaragenan dengan metode emulsi akan menghasilkan beads mikrokapsul berukuran 0,5-1 mm. SRC jenis Eucheuma cottonii adalah Semi Refine Caragenan, yang dibuat melalui proses ekstraksi dengan metode PNG (philipine Natural Grade). Tahapan dalam proses ekstraksinya menggunakan alkali $\mathrm{KOH}$ sebgai bahan ekstraksi, suhu $72-75^{\circ} \mathrm{C}$ selama 2jam, penetralan, pemotongan, pengeringan, penepungan, pengepakan. Hasilnya adalah perubahan dari kandungan 6 sulfat pada posisi $\beta$ 1,4 galaktosa menjadi 3,6 anhydrogalaktosa atau 3,6 AG, sehingga dengan perubahan ini akan mempengaruhi kekuatan gel, gelling point, melting point, kekuatan hidrasi, $\mathrm{pH}$, ketahanan terhadap suhu, kestabilan terhadap asam., serta kelarutannya. (Imeson, 1998)

SRC jenis Eucheuma cottonii merupakan bahan penyalut yang mempunyai sifat-sifat sebagai berikut: 1). gugus hidroksil dan sulfat pada SRC bersifat hidrofilik, oleh karena itu polimer tersebut dikelilingi oleh molekul-molekul air yang terimobilisasi, sehingga menyebabkan larutan SRC bersifat kental (Guiseley et al., 1980). Pembentukan gel disebabkan karena terbentuknya struktur heliks rangkap yang tidak terjadi pada suhu tinggi. Pada $\mathrm{pH}$ asam SRC mudah terhidrolisis, sedangkan pada $\mathrm{pH}$ basa SRC sulit terhidrolisis ,tetapi stabil dalam bentuk gel (Glicksman, 1983). Salah satu sifat fisik yang penting pada SRC adalah kekuatan untuk membentuk gel yang disebut sebagai kekuatan gel. Sifat inilah yang berhubungan dengan kemampuannya sebagai bahan penyalut.

Probiotik adalah inti/salut dari kelompok bakteri asam laktat yang mempunyai fungsi menyehatkan dan penting bagi kesehatan. Probiotik adalah mikroorganisme hidup yang apabila diberikan pada host, baik manusia maupun hewan, dalam jumlah cukup akan memberikan manfaat kesehatan (FAO/WHO, 2002). Probiotik yang mencapai saluran pencernaan hingga $10^{7}$ $\mathrm{cfu} / \mathrm{mL}$ atau gram akan menunjukkan efek fungsional probiotik. Mikroflora probiotik yang memproduksi asam laktat biasanya berasal dari golongan 
Lactobacilli dan Bifidobacteria (Mc Farlane et al.2006).

Bakteri

Lactobacillus

acidophilus menunjukkan fase stationer yang pendek serta diikuti kehilangan viabilitas sel yang cepat, walaupun disimpan pada suhu beku. (Charampopoulus et al. 2002). Pendeknya waktu hidup probiotik ini menjadikan permasalahan tentang bagaimana cara mempertahankan viabilitas probiotik ini agar tetap memberikan efek fungsional. Salah satu cara mempertahankan viabilitas adalah dengan cara mikroenkapsulasi.

Enkapsulasi diterapkan pada probiotik dengan tujuan untuk melindungi probiotik tetap hidup dari kondisi ekstrim akibat pengeringan, penyimpanan maupun cairan saluran pencernaan. Guerin et al. (2003) menunjukkan bahwa probiotik yang dienkapsulasi mempunyai viabilitas yang lebih tinggi pada perlakuan kondisi saluran pencernaan dibanding tanpa terenkapsulasi.Perlakuan pada larutan pH 2 dan pH 7 merupakan cara simulasi untuk melihat pengaruh $\mathrm{pH}$ Gastro Intestinal saluran pencernaan bagian atas terhadap viabilitasnya.
Tujuan dari penelitian ini adalah mempelajari karaginan dalam bentuk SRC jenis Eucheuma cottonii sebagai bahan penyalut Lactobacillus acidophilus terhadap viabilitas dalam kondisi $\mathrm{pH}$ berbeda dalam proses mikroenkapsulasi.

\section{BAHAN DAN METODE}

Bahan penelitian adalah:1) Rumput laut jenis Eucheuma cottonii yang dipanen dari perairan Lombok Kepulauan ,2) biakan Lactobacillus acidophilus koleksi Laboratorium Mikrobiologi Fakultas Kedokteran Universitas Brawijaya Malang ,3) MRS Agar .

Metode penelitian adalah laboratorium experimental, data yang diperoleh dianalisis dengan ANOVA untuk menentukan pengaruh berbeda, dilanjutkan dengan Least Significance Difference ( LSD ) untuk melihat perbedaan antar perlakuan, dengan menggunakan software SPSS. Struktur mikrokapsul diamati secara deskriptif menggunakan Confocal Laser Scanning Microscope (CLSM) 
Penelitian dilakukan dengan metoda pengujian:

Kualitas SRC Eucheuma cottonii dengan parameter dan prinsip pengujian meliputi a)Kadar air menggunakan metode pengeringan dengan oven, dikeringkan pada suhu $100-102^{\circ} \mathrm{C}$ sampai mendapatkan berat yang konstan(AOAC, 1995), b)kadar abu menggunakan metoda pengabuan kering yaitu bahan organik dibakar dalam suatu tanur sampai suhu $500-600 \quad{ }^{\circ} \mathrm{C}$ (AOAC,1995), c)Total sulfat dengan menggunakan metoda pengendapan menggunakan BaSO4, dengan prinsip gugus sulfat yang telah dihidrolisa diendapkan sebagai BaSO4 (FMC, 1977), d)kekuatan gel (gel strength) diukur dengan menggunakan alat pnetrometer, hasil pengukuran dinyatakan

1) dalam dyne $/ \mathrm{cm}^{2}$, e)gelling point diukur berdasarkan titik jendal

2) dari sampel

dengan menggunakan termometer digital merk Hanna. Penentuan titik jendal dilakukan dengan mempersiapkan larutan karaginan dengan konsentrasi $6,67 \%$ dengan aquadest (w/v) dalam gelas ukur. Suhu sampel diturunkan perlahan-lahan. Titik jendal diukur pada saat karaginan membentuk gel (Suryaningrum dan Utomo, 2002), f)melting point adalah mengukur titik leleh dari sampel karaginan, dengan cara memanaskan gel sampel dalam waterbath. Diatas gel karaginan diletakkan gotri dan ketika gotri jatuh kedasar gel, maka suhu tersebut dinyatakan senbagai titik leleh (Suryaningrum dan Utomo, 2002), g) viscositas adalah pernyataan tahanan dari suatu cairan untuk mengalir. Pengujian dilakukan dengan melarutkan karaginan dengan konsentrasi $1,5 \%$ dengan aquadest, dipanaskan sampai suhu mencapai $\quad 75^{\circ} \mathrm{C}$. Viscositas diukur dengan menggunakan alat Vicometer merk Brookfield. Hasil pengukuran dinyatakan dalam dPas atau cPas (FMC,1977), h)gugus fungsi menggunakan FTIR.Prinsip pengujian adalah absorbsi gugus karbonil menggunakan serapan Infra merah. Pengukuran absorbsi radiasi Infra Red pada berbagai panjang gelombang dilakukan dengan spektrofotometer Infra 
Red Shimadzu model IR-430 (Simorangkir, 2004)

1) pH 2 dan pH 7 dengan metoda aquadest ditambah larutan $\mathrm{HCl}$ dan larutan Phospat Buffer.

2) Pengujian

Lactobacillus

viabilitas

menggunakan

acidophilus

metoda tuang dengan seri pengenceran ;

3) Struktur

mikrokapsul

Lactobacillus

acidophilus

dengan menggunakan alat Confocal Laser Scanning Microscope (CLSM).

Prosedur kerja

penelitian

melalui langkah :

Pembuatan SRC jenis Eucheuma cottonii dengan metode PNG (FMC biopolimer) melalui langkah : rumput laut jenis Eucheuma spinosum kering ditimbang, dibersihkan dan dicuci. Kemudian rumput laut di rebus dalam larutan $\mathrm{KOH}$ dengan konsentrasi $6 \%(\mathrm{w} / \mathrm{v})$ dengan suhu $70-74^{\circ} \mathrm{C}$ selama 2 jam. Diambil dan dicuci dengan air bersih sampai bau $\mathrm{KOH}$ hilang (penetralan). Setelah itu rumput laut dikeringkan, digiling.

1) Selanjutnya dilakukan analisa kualitas secara fisiko kimia dan gugus fungsi ;

2) Persiapan kultur Lactobacillus acidophilus (Lay, 1994);

3) Pembuatan produk mikrokapsul Lcatobacillus acidophilus metode emulsifikasi ( Adhikari,2003);

4) Skema pengujian mikrokapsul Lactobacillus acidophilus yang tersalut bahan Semi Refine Caragenan jenis Eucheuma spinosum terhadap viabilitas dan struktur mikrokapsul pada kondisi kontrol, kondisi $\mathrm{pH} 2$ dan kondisi $\mathrm{pH} 7$;

5) Pengamatan struktur mikrokapsul Lactobacillus acidophilus secara deskriptif menggunakan Confocal Laser Scanning Microscope CLSM);

6) Analisa data menggunakan software SPSS. 
Jurnal Teknologi Pangan Vol.2 No.1

November 2011

\section{Uraian langkah proses}

1. Pembuatan Kultur Lactobacillus acidophilus

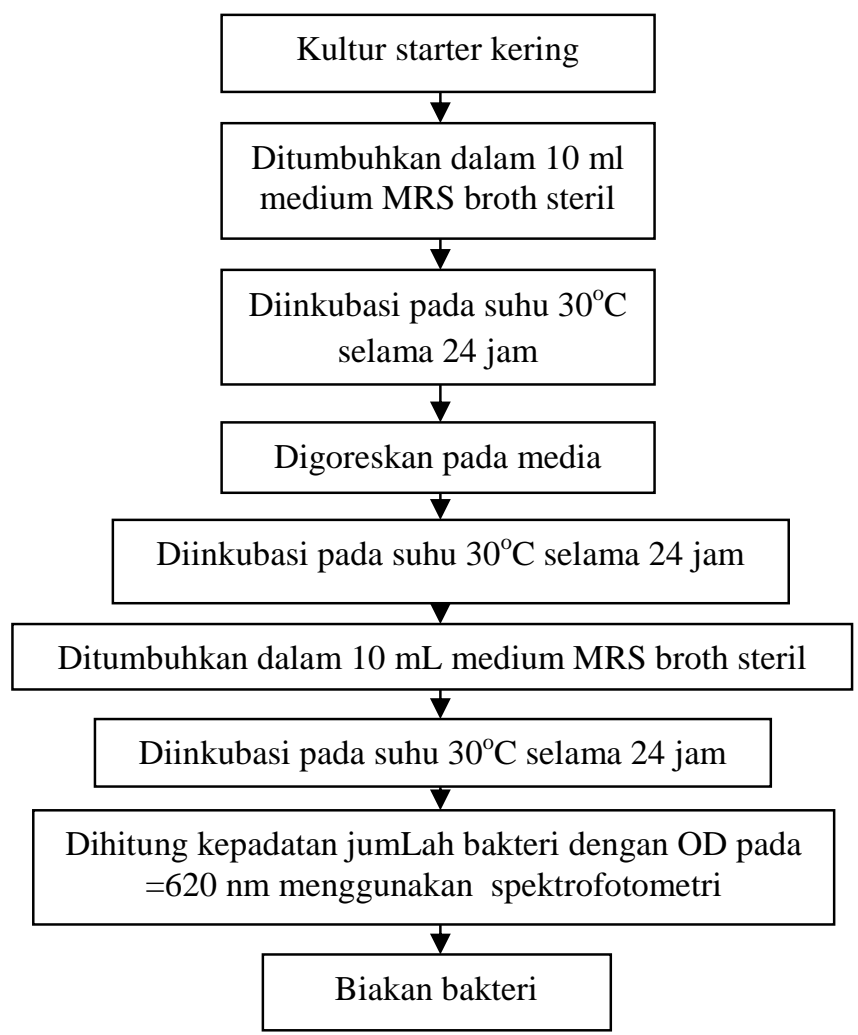

Gambar1.Pembuatan Kultur Bakteri Lactobacillus acidophilus (Lay,1994) Figure 1 . Making of Lactobacillus acidophilus bacterial culture (Lay, 1994) 
Jurnal Teknologi Pangan Vol.2 No.1

November 2011

\section{Pembuatan Mikrokapsul Lactobacillus Acidophilus}

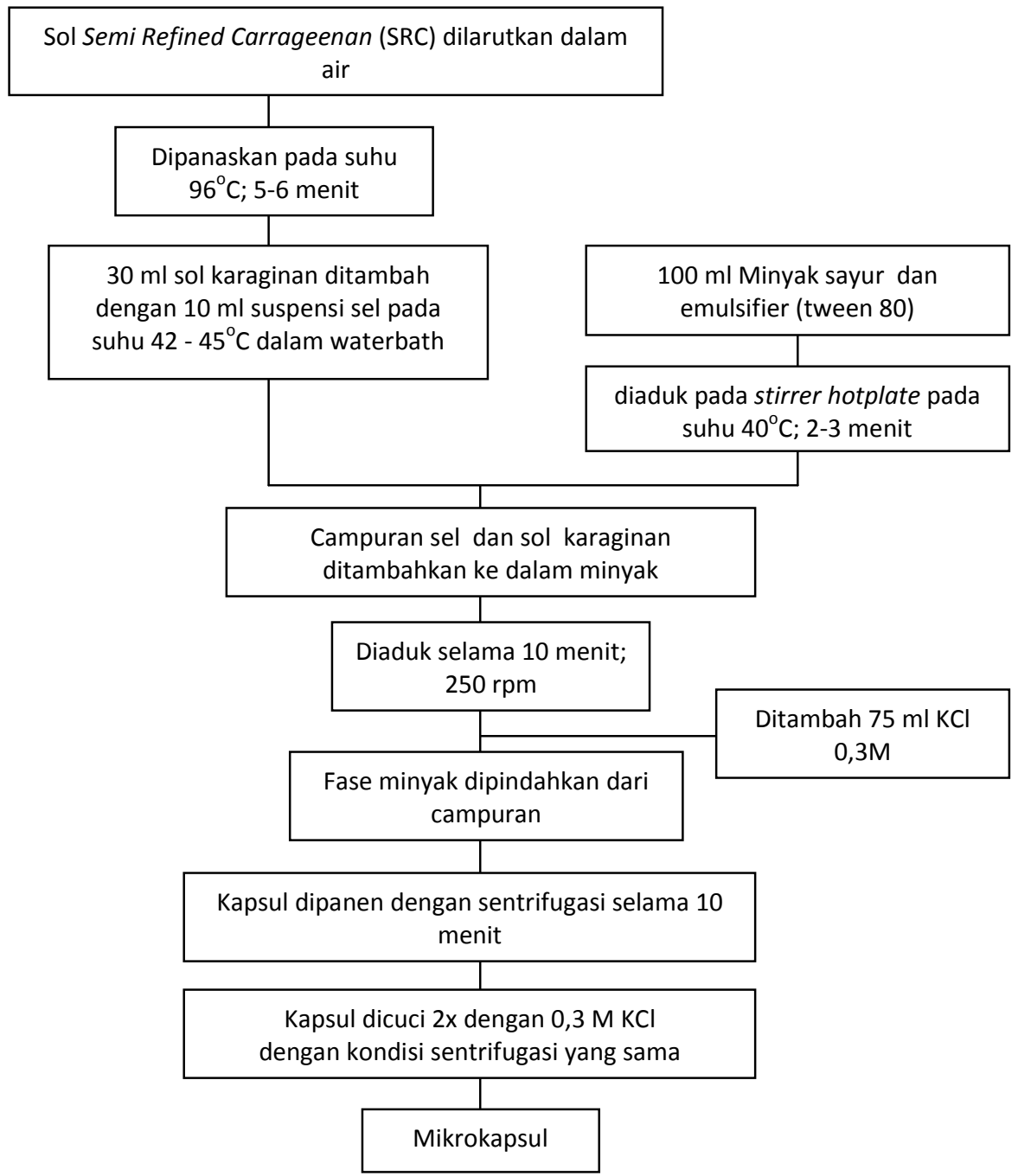

Gambar 2. Proses Mikroenkapsulasi Lactobacillus acidophilus (Adhikari, 2003) Figure 3. Lactobacillus acidophilus microencapsulation processing (Adhikari,2003) 
Jurnal Teknologi Pangan Vol.2 No.1

November 2011

3. Skema pengujian mikrokapsul Lactobacillus acidophilus yang tersalut bahan Semi Refine Caragenan jenis Eucheuma cottonii .

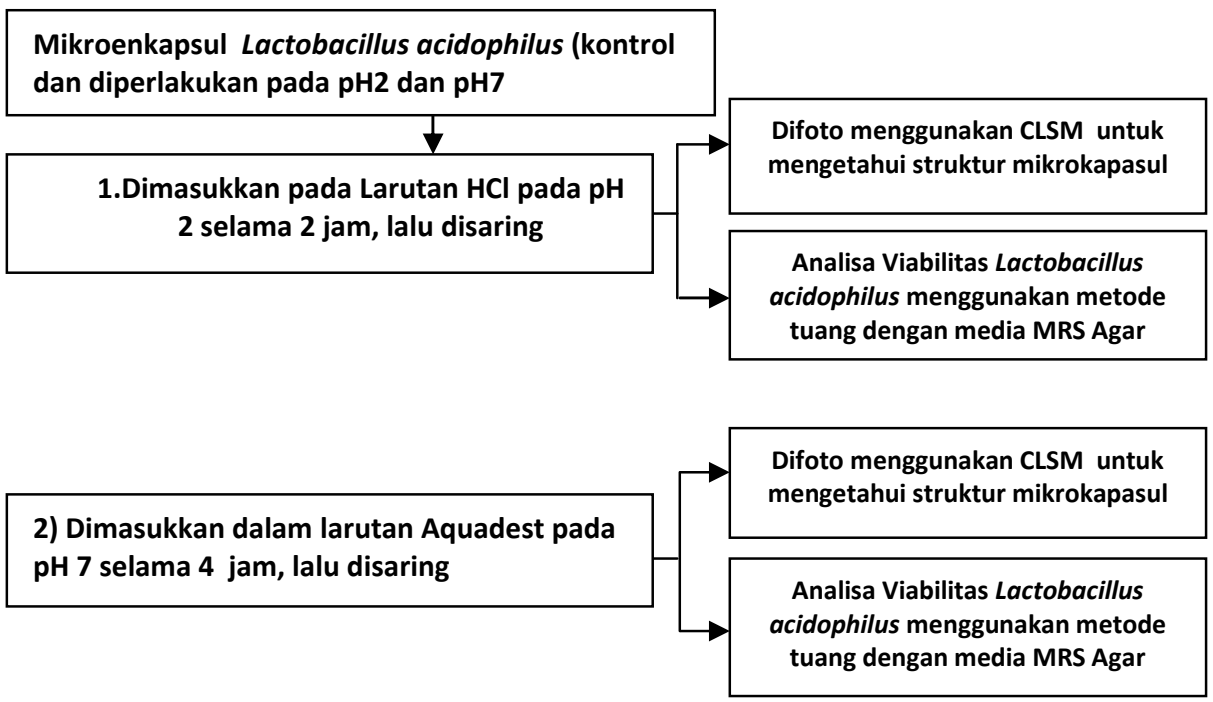

Gambar 3. Langkah pengujian mikrokapsul Lactobacillus acidophilus Figure 3. Step of Lactobacillus acidophilus microcapsules analysed 
HASIL DAN PEMBAHASAN

Hasil Analisis Fisiko Kimia

Semi Refined Carrageenan (SRC) Eucheuma cottonii dapat dilihat pada Tabel 1.

Tabel 1. Analisis kualitas SRC Eucheuma cottonii

Table 1. quality analysed of SRC Eucheuma cottonii

\begin{tabular}{|l|c|}
\hline \multicolumn{1}{|c|}{$\begin{array}{c}\text { Parameter - } \\
\text { Satuan }\end{array}$} & $\begin{array}{c}\text { SRC Eucheuma } \\
\text { cottonii }\end{array}$ \\
\hline Air $(\%)$ & 10,6 \\
\hline Abu $(\%)$ & 18,7 \\
\hline Total $\mathrm{SO}_{4}(\%)$ & 28,8 \\
\hline gel strength (dyne/mm2) & 1060 \\
\hline Gelling point $\left({ }^{\circ} \mathrm{C}\right)$ & 25,2 \\
\hline Melting point $\left({ }^{\circ} \mathrm{C}\right)$ & 80,2 \\
\hline $\begin{array}{l}\text { Viskositas (add } \\
\left.1,5 \%, 75^{\circ} \mathrm{C}\right) \mathrm{cPas}\end{array}$ & 180 \\
\hline
\end{tabular}

Dari gambar 4 dibawah ini penentuan gugus fungsional karaginan dengan menggunakan metoda FTIR dapat diketahui bahwa karaginan yang dihasilkan SRC jenis Eucheuma cottonii memiliki sifat polisakarida yaitu larut dalam air,dimana dapat diketahui dengan adanya gugus hidroksil pada panjang gelombang $3371.34 \mathrm{~cm}^{-1}$. sedangkan panjang gelombang $\quad 1167,82 \quad \mathrm{~cm}^{-1}$ menunjukan total sulfat, panjang gelombang $\quad 850,55 \quad \mathrm{~cm}^{-1}$ menunjukan anhidro galaktosa ester sulfat posisi 4, dan panjang gelombang 806.19 menunjukan ester sulfat posisi 2 . 
Jurnal Teknologi Pangan Vol.2 No.1

November 2011

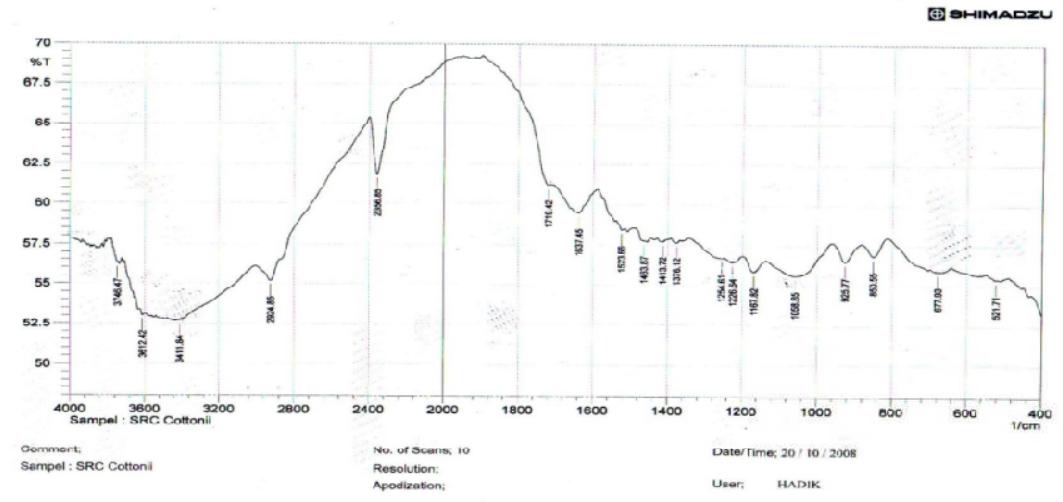

Gambar 4. Analisa FTIR SRC Eucheuma cottonii Figure 5. Eucheuma cottonii FTIR analysed

\begin{tabular}{llrlr}
\multicolumn{2}{c}{ Penggunaan spektroskopi } & Penunjukan gugus fungsi serta \\
inframerah dalam & rangka & intensitas serapan dapat digunakan \\
mengidentifikasi adanya gugus & untuk membedakan tipe \\
fungsi, sehingga & dapat & karaginannya & (Satari, 1996). \\
membedakan tiap tipe karaginan. & Sejalan dengan pendapat Phycoll
\end{tabular}


(2009) gugus fungsi kappakaraginan dapat dilihat pada panjang gelombang yang tertera pada Tabel 2.

Tabel 2. Analisa FTIR kappacaragenan

Table 2. Kappa-caragenan FTIR analyzed

\begin{tabular}{|c|c|}
\hline $\begin{array}{c}\text { Panjang } \\
\text { Gelombang } \\
\text { (cm-1) }\end{array}$ & Gugus Fungsi \\
\hline 1.250 & total sulfat \\
\hline 930 & anhidro galaktosa \\
\hline 850 & ester sulfat posisi 4 \\
\hline 805 & ester sulfat posisi 2 \\
\hline
\end{tabular}

Sumber : Phycol (2002)

Perbedaan struktur karaginan terletak pada kandungan 3,6Anhydrogalactosa dan ester sulfat. Perbedaan variasi ini akan mempengaruhi hidrasi, gel strength, tekstur, melting point dan setting point, sineresis. Perbedaan ini juga dipengaruhi oleh jenis rumput laut, metoda proses ekstraksi yang berbeda. Sedangkan Bahan ekstraksi yang menggunakan ion Kalium pada kappa-caragenan yang dihasilkan dari proses SRC jenis Eucheuma cottonii akan memberikan ikatan pada jembatan double junction, sehingga akan memberikan tipe gels yang kokoh dan rigid (Phillips and William, 2001).

Pengujian mikrokapsul Lactobacillus acidophilus terhadap viabilitasnya pada kondisi kontrol, kondisi pH 2 dan kondisi pH 7 secara in vitro.

Hasil analisa menggunakan ANOVA perlakuan kondisi kontrol, $\mathrm{pH} 2$, pH 7 menunjukkan pengaruh berbeda sangat nyata $(\mathrm{p}<0.01)$ dengan nilai Adjusted Rsquare 0,97 .

Hasil analisis perbedaan menggunakan uji Least Significance Difference (LSD) viabilitas Lactobacillus acidophillus setelah di enkapsulasi (SRC) Eucheuma cottonii dengan perlakuan kondisi berbeda dapat di lihat pada Tabel 3 .

Tabel 3. Uji LSD viabilitas Lactobacillus acidophillus setelah di enkapsulasi SRC Eucheuma cottonii dengan perlakuan kondisi pH berbeda

Table 4.LSD analysed of Lactobacillus acidophilus viability after encapsulated by SRC 
Eucheuma cottonii in difference pH condition treatment

\begin{tabular}{|l|l|l|}
\hline $\begin{array}{l}\text { Kondisi } \\
\mathrm{pH}\end{array}$ & $\begin{array}{l}\text { Mean (log } \\
\text { cfu/ml) }\end{array}$ & Std.Deviation \\
\hline $\begin{array}{l}\text { Kontrol } \\
\text { pH2 }\end{array}$ & 6,3207 a) & $\pm 0,1236$ \\
pH7 & 2,1929 b) & $\pm 0,2953$ \\
\hline 00,1387 \\
\hline
\end{tabular}

*)rata-rata yang didampingi notasi huruf sama menunjukkan tidak berbeda nyata

Rata-rata perlakuan memberikan pengaruh berbeda sangat nyata baik pada kondisi kontrol, kondisi $\mathrm{pH} 2$ dan kondisi pH7 terhadap viabilitas Lactobacilus Acidophilus dan terjadi pengurangan jumlah viabilitas pada kondisi kontrol, pada $\mathrm{pH} 2$ dan $\mathrm{pH} 7$ dari $10^{6} \mathrm{cfu} / \mathrm{mg}$ menjadi $10^{3} \mathrm{cfu} / \mathrm{mg}$ dan $10^{2}$ cfu/mg. Hal ini diduga karena konsentrasi SRC yang digunakan belum mampu memberikan perlindungan terhadap Lactobacillus acidophilus. Salah satu faktor yang mempengaruhi pembentukan mikrobeads dan viabilitas tergantung kepada konsentrasi bahan penyalut. Semakin tinggi konsentrasi bahan penyalut, semakin besar viabilitasnya. Sedangkan Ding W.K, and Shah N.P,( 2009) probiotik yang disalut dengan caragenan dan xanthan gum sama seperti alginat mempunyai kemampuan melindungi viabilitas probiotik dibandingkan tanpa enkapsulasi pada kondisi $\mathrm{pH} 2$ dan konsentrasi dari garam empedu yang tinggi .Pengaruh $\mathrm{pH} 2$ selama 2 jam dengan bahan penyalut gum caragenan konsentrasi 2\% akan memberikan viabilitas probiotik sebesar $10^{6} \mathrm{cfu} / \mathrm{ml}$.

Caragenan dalam bentuk larutan akan kehilangan viskositas dan gel strength, jika berada dalam sistim $\mathrm{pH}$ dibawah 4,3. Efek ini disebabkan karena autohidrolisis yang terjadi pada $\mathrm{pH}$ rendah, karena pelepasan ikatan molekul 3,6 Anhydrogalaktosa (Hoffman, Russel and Gidley, 1996). Kecepatan autohidrolisis meningkat seiring dengan kenaikan temperatur dan tingkat kation yang rendah. Penggunaan $\mathrm{pH}$ dibawah 3 dan temperatur $40^{\circ} \mathrm{C}$ akan mengurangi Gel strength sebesar $25 \%$. Penurunan jumlah viabilitas Lactobacillus acidophilus setelah $\mathrm{pH}$ 2, diduga karena pengaruh faktor tersebut, walaupun disebutkan sifat iota caragenan dalam bentuk gel adalah stabil pada $\mathrm{pH}$ rendah. Ketidak mampuan mempertahankan viabilitas 107 cfu/ml sesuai standar WHO/FAO setelah $\mathrm{pH} 7$ diduga karena struktur gel matriks dari produk 
SRC Eucheuma cottonii kurang rapat, sehingga lingkungan eksternal seperti $\mathrm{pH}$ dapat mempengaruhi viabilitas Lactobacillus acidophilus.

Pengamatan dengan Confocal Laser Scanning Microscope (CLSM)

Mikrokapsul Lactobacillus acidophilus yang tersalut SRC Eucheuma cottonii setelah perlakuan $\mathrm{pH} 2$ diamati dengan CLSM mempunyai diameter sebesar $80 \mu \mathrm{m}$ dan setelah perlakuan pH 7 adalah $60 \mu \mathrm{m}$. Hal ini dapat disimpulkan bahwa bulatan-bulatan yang didapat berukuran mikro karena memiliki ukuran <5000 um. Menurut Risch dan Reineccius (1995) membagi mikroenkapsulat berdasar ukuran menjadi tiga, yaitu makroenkapsulat (> $5000 \mu \mathrm{m})$, mikroenkapsulat $(0,2 \mu \mathrm{m}-5000$ $\mu \mathrm{m})$ dan nanomikroenkapsulat $(<0,2 \mu \mathrm{m})$.

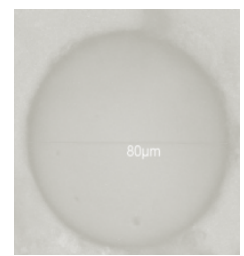

(a)

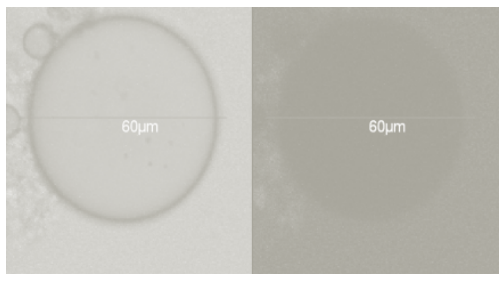

(b)

Gambar 6.(a) Mikrokapsul setelah perlakuan pH 2

(b) Mikrokapsul setelah perlakuan pH 7

Figure 6. (a)Microcapsule after $\mathrm{pH} 2$ condition treatment

(b)Microcapsule after pH7 condition treatment

\section{Kesimpulan}

1. Kualitas fisikokimia SRC jenis Eucheuma cottonii adalah kadar air sebesar $11,6 \%$, kadar abu $18,5 \%$, kadar sulfat $28 \%$, kekuatan gel 1060 dyne $/ \mathrm{cm}^{2}$, gelling point $23,8{ }^{\circ} \mathrm{C}$, melting point $80,4^{\circ} \mathrm{C}$, viscositas 180 cPas.

2. Karakteristik gugus fungsi menggunakan FTIR SRC jenis Eucheuma cottonii ditandai dengan sifat polisakarida yang larut dalam air,dimana dapat diketahui dengan adanya gugus hidroksil pada panjang 


\begin{tabular}{|c|c|}
\hline gelombang & Saran \\
\hline Sedangkan pada panjang & faktor \\
\hline $1167,82 \mathrm{~cm}^{-1}$ & mempengaruhi \\
\hline menunjukan total sulfat, & ntung pada ko \\
\hline anjang gelombang $931.55 \mathrm{~cm}^{-}$ & yalut,maka disara \\
\hline $\begin{array}{l}\text { enunjukan annidro galaktos: } \\
\text { injang gelombang } 850.55 \mathrm{~cm}\end{array}$ & menggunakan konsentrasi \\
\hline $\begin{array}{l}\text { enunjukkan ester sulfat pc } \\
\text { dan panjang gelomb }\end{array}$ & $\begin{array}{l}\text { lebih tinggi untuk diteliti leb } \\
\text { lanjut. }\end{array}$ \\
\hline
\end{tabular}
$806.19 \mathrm{~cm}^{-1}$ menunjukan ester sulfat posisi 2.

3. Perlakuan pada kondisi berbeda memberikan pengaruh berbeda sangat nyata terhadap viabilitas Lactobacillus acidophilus pada kondisi kontrol, berbeda pada kondisi pH 2 dan berbeda pada kondisi $\mathrm{pH} 7$ secara invitro. Rata-rata viabilitas Lactobacillus acidophilus pada berbagai kondisi perlakuan berbeda mengalami penurunan dari $10^{6} \mathrm{cfu} / \mathrm{ml}$ menjadi $10^{3}$ $\mathrm{cfu} / \mathrm{ml}$ pada $\mathrm{pH} 2$ dan menjadi $10^{2} \mathrm{cfu} / \mathrm{ml}$ pada $\mathrm{pH} 7$.

4. Pengamatan mikrokapsul Lactobacillus acidophilus dengan CLSM mempunyai ukuran ukuran $80 \mu \mathrm{m}$ pada kondisi pH 2 dan berukuran 60 $\mu \mathrm{m}$ setelah melewati perlakuan pH 7 secara in vitro.

\section{Ucapan terima kasih}

Kepada Kementrian Pendidikan Nasional Republik Indonesia melalui DirJen Dikti yang telah mendanai penelitian ini melalui Penelitian Hibah Fundamental tahun anggaran 2009/2010.

\section{Daftar Pustaka}

Adhikari K, A., Mustapha, et al. 2003.Survival and metabolic activity of microencapsulated Bifidobacterium longum in stirred yogurt. Journal of Food Science. Vol 68, Nr.1.

Chibata,I . 1981. Immobilized microbial cells with polyacrylamide gel and carragenan and their industrial application, In immobilized cells (ed K. 
Venkatsubramanian)

Am.Chem.Soc.Symp.Ser.,10

6,187-202

Ding. W.K., and Shah N.P. 2009. Effect of Various Encapsulating Materials on the Stability of Probiotic Bacteria. Journal of Food Science. 74: 100-107.

FAO/WHO. 2002. Guidelines for the Evaluation of Probiotics in Food. London, Ontario, Canada, April 30 and May 1

Guerrin, , D., Vuillemard, J.C. and Subirade, M. 2003. Protection of bifidobacteria encapsulated in polysaccharide-protein gel beads against gastric juice and bile. J Food Prot. 66: 2076-2084.

Glicksman,M. 1983.Gum Technology In The Food Industry, New York; Academic Press, p 214-224

Glicksman. 1983. Food Hydrocolloids. Volume I. Florida: CRC Press Boca Raton. 207 p.
Hoffman,R.A., Russel A.I., Gidley,M.J. 1996. Gums and stabilizer for the food Industry 8,137 ff.,(eds) G.O, Phillips,P.A Williams and D.J Wedlock, Oxford university Press,Oxford.

Imeson, 1998. Carrageenan.In G.O., Phillips and P.A William (Eds) Handbook Of Hydrocolloids (pp 87102).cambridge., Woodhead Publishing Ltd.

Kondo .1979. Microcapsule Processing And Technology, New York; Marcel Dekker.

Macfarlane S, Macfarlane GT and Cummings JH. 2006. Review article: prebiotics in the gastrointestinal tract. Aliment Pharmacol Ther. 24: 701-714

Mosilhey. 2003.Influence Of Difference Capsule Material On The Physiological Properties Of Microencapsulated Lactobacillus acidophilus. Dissertation. Rheinischen Friedrich-Wilhelms University, Bonn. 
Philip and William. 2001. Handbook of Hydrocolloids. CRC Press Boca raton Boston New York Washington. D.C.p 87-102

Risch and Reineccius GA .1995. Encapsulation \& Controlled Release Of Food Ingredients.ACS

Symposium Series 590.
Washington DC. American Chemical Society.

Satari. 1996.karakteristik polisakarida Karagenan Asal Eucheuma sp dan Hypnea sp. Puslitbang Oceanology LIPI. Seminar Industri rumput Laut. Jakarta Utara 